\title{
PENINGKATAN EFIKASI DIRI MASYARAKAT DALAM PENCEGAHAN TUBERKULOSIS BERBASIS BUDAYA
}

\author{
R Endro Sulistyono*, Tintin Sukartini**, Makhfudli**, Nursalam**, \\ $\operatorname{Rr}$ Soenarnatalina $\mathrm{M}^{* * *}$, Laily Hidayati** \\ *Mahasiswa Magister Keperawatan Universitas Airlangga \\ Email: radendro1988@gmail.com \\ ** Fakultas Keperawatan Universitas Airlangga \\ *** Fakultas Kesehatan Masyarakat Universitas Airlangga
}

\begin{abstract}
Numbers of TB in Indonesia are increasing by years. One of the causes of TB control challenges is the lack of community awareness of TB disease. The Madurese are very culturally and very obedient to the kiai (religious leaders) as well as the level of TB disease in areas where they are still high. This study aimed to explore the community's self-efficacy towards TB prevention through a cultural approach. Method: This study is a quasi experimental study with two control and treatment groups (pre-post design). The sample of this study were 100 respondents (50 controls groups and 50 treatment groups) which selected by simple random sampling based on the inclusion criteria. Data then analyzed by using paired t test dan independent $t$ test. Result: there was significant effect of $\mathrm{P}$ value $=0.000$ in treatment group, there was self efficacy improvement after the delivery of intervention with culture approach. Discussion: Interventions for TB prevention require innovation with cultural approaches adopted by the community (such as working with kiai, people who are considered to have charisma for certain community groups) to make it easier to implement $\mathrm{TB}$ prevention.
\end{abstract}

Keywords : Tuberculosis, culture, efficacy

Abstrak: Angka TB di Indonesia semakin meningkat. Salah satu hal yang menjadi tantangan dalam penanganan TB adalah kurangnya kesadaran dan kepedulian masyarakat terhadap penyakit TB. Etnik Madura sangat kental budayanya dan sangat patuh pada kiai (tokoh agama) serta tingkat penyakit TB di daerah-daerah yang banyak didiami oleh mereka masih tinggi serta. Penelitian ini bertujuan untuk mengeksplorasi efikasi diri masyarakat terhadap pencegahan TB melalui pendekatan budaya.Metode: penelitian ini merupakan penelitian quasy eksperiment dengan 2 kelompok kontrol dan perlakuan (pre-post desain). Sampel penelitian ini berjumlah 100 responden (50 orang kelompok kontrol dan 50 orang kelompok perlakuan) yang dipilih dengan simple random sampling berdasar kriteria inklusi. Analisa data menggunakan uji paired t test dan independent t test dengan $\alpha \leq 0,05$. Hasil: ada pengaruh yang signifikan $\mathrm{P}$ value $=0,000$ pada kelompok perlakuan yaitu peningkatan efikasi diri setelah pemberian intervensi berbasis budaya dibanding kelompok kontrol. Diskusi: Intervensi untuk pencegahan TB memerlukan inovasi dengan pendekatan budaya yang dianut masyarakat (seperti bekerja sama dengan kiai, pakar, orang yang dianggap memiliki kharisma bagi golongan masyarakat tertentu) agar lebih mudah melaksanakan pencegahan TB.

Kata kunci : Tuberkulosis, budaya, efikasi

PENDAHULUAN

Tuberkulosis (TB) Paru masih menjadi permasalahan kesehatan dunia. TB masih menjadi penyakit yang menyebabkan mortalitas di Negara berkembang. Data World Health Organization tahun 2013 memperkirakan 9,6 
juta kasus TB baru, sedangkan di Indonesia kasus TB baru diperkirakan 1 juta kasus (399 per 100,000 penduduk) (WHO, 2013). Indonesia telah mengimplementasikan "TOSS" yang merupakan akronim Temukan, Obati TB Sampai Sembuh (TB Indonesia, 2016) untuk peningkatan penemuan kasus baru TB. Tujuan utama skrining penemuan kasus adalah mendeteksi secara dini klien TB (WHO, 2013). Indonesia menerapkan Directly Observed Treatment Short Course (DOTS) sebagai strategi pengendalian TB yang lebih menekankan pada penemuan pasif dengan cara promosi kesehatan secara aktif (Ditjen P2P, 2016).

Angka penderita TB di Lumajang sebanyak 707 orang sedangkan jumlah perkiraan pasien TB baru sebanyak 1.077 orang (Dinkes Lumajang, 2014). Studi pendahuluan dengan metode studi dokumentasi mencatat bahwa dari 25 puskesmas yang ada di Lumajang, angka tertinggi penemuan kasus baru terdapat di Puskesmas Pasirian (jumlah warga 51.157 jiwa sebagaian besar merupakan suku Jawa dan Madura) yaitu sebanyak 44 jiwa (estimasi sebanyak 57 jiwa) dan 4 diantaranya meninggal (Dinkes Lumajang, 2014). Penyakit TB akan berdampak pada besarnya biaya yang dikeluarkan untuk perawatan, dan gangguan dalam keluarga. Dengan semakin meningkatnya kasus TB, pencegahan dan manajemen penyakit TB juga semakin menantang bagi tenaga kesehatan (WHO, 2009).

TB merupakan penyakit yang dapat dicegah melalui identifikasi secara tepat proses transimi kuman TB (Arshad, Salam, \& Bhutta, 2014). WHO (2006) menyatakan bahwa beberapa hal yang menyebabkan tantangan kontrol TB adalah kurangnya kesadaran dan kepedulian masyarakat terhadap penyakit TB (Turk, Newton, Newton, Naureen, \& Bokhari, 2013). Kasus baru TB yang gagal ditemukan akan mengakibatkan dampak pada tingkat individu yaitu keterlambatan pengobatan yang akan memperburuk kondisi penyakit dan pada tingkat epidemi akan meningkatkan durasi periode infeksi sehingga meningkatkan penularan TB ke orang lain. Penemuan kasus TB yang kurang baik akan berdampak pada peningkatan insiden TB dan angka mortalitas juga meningkat (Arias et al., 2010).
Masyarakat ada yang masih menganggap bahwa TB merupakan penyakit guna-guna, kutukan, dan keturunan. Adanya pandangan negatif/stigma ini menyebabkan penderita malu dan enggan ke pelayanan kesehatan. Beberapa masyarakat juga acuh-tak acuh dengan anggota keluarga ataupun tetangga yang mengalami batuk lebih dari 2 minggu. Keterlibatan masyarakat sangat dibutuhkan dalam menyukseskan strategi end TB. Perubahan perilaku dari acuh menjadi peduli merupakan proses yang cukup rumit. Salah satu hal yang mempengaruhi seseorang berperilaku adalah efikasi diri. Keyakinan efikasi diri seseorang akan mempengaruhi seseorang dalam memilih tindakannya, jumlah usaha yang akan dilakukan, ketahanan dalam menghadapi suatu masalah, pola pikir, tingkat stres dan tingkat pencapaian akan suatu hal (Baldwin, Baldwin, \& Ewald, 2006). Individu yang sadar (efikasi diri tinggi) dengan apa yang menjadi permasalahan kesehatan maka orang tersebut semakin ahli dalam menggunakan kemampuannya untuk mewujudkan apa yang perlu dilakukan (Neil \& Christensen, 2009).

Dalam suatu masyarakat, selalu dijumpai satu atau sekelompok individu yang memiliki pengaruh yang sering menentukan kehidupan dan perubahan masyarakat. Penduduk Madura mayoritas memeluk Islam yang kemudian hal ini menempatkan tokoh agama (kiai) pada posisi yang sangat penting dan sentral di tengah masyarakat. Bahkan, bagi masyarakat Madura, kiai dipandang tidak hanya sebagai subyek yang mengajarkan ilmu-ilmu agama, tetapi juga sebagai subyek yang mempunyai kekuatan lebih (Rozaki, 2004). Kharisma kyai memperoleh dukungan masyarakat (hingga batas tertentu) karena dipandang memiliki kemantapan moral dan kualitas iman yang melahirkan model kepribadian magnetis bagi para pengikutnya (Susanto, 2007).

Asuhan keperawatan (care) dan budaya (culture) merupakan dua hal yang saling terikat dan berhubungan. Pemahaman terhadap budaya akan menjadikan asuhan keperawatan menjadi lebih terarah, inovatif dan pada akhirnya dapat meningkatkan pelayanan kesehatan (Andrew \& Boyle, 2003). Masyarakat dengan keragaman suku dan budaya akan memiliki penerimaan 
berbeda terhadap masalah kesehatan oleh karena itu model keperawatan transkultural diperlukan sebagai pedoman dalam melakukan intervensi supaya tidak terjadi cultural shock (Leininger \& McFarland, 2006). Peran dan kharisma kiai di komunitas Madura yang sangat dihormati baik di bidang keagamaan maupun bidang kesehatan diharapkan dapat menjembatani transformasi informasi dari petugas kesehatan ke masyarakat setempat (Fauzan, 2014). Penelitian ini bertujuan untuk mengeksplorasi efikasi diri masyarakat dalam pencegahan TB melalui pendekatan budaya.

\section{METODE}

Penelitian ini merupakan penelitian quasy eksperiment yaitu mengungkapkan suatu hubungan sebab akibat dengan cara melibatkan kelompok kontrol disamping kelompok perlakuan tetapi tidak sepenuhnya memenuhi 3 kriteria yaitu replikasi, randomisasi dan kontrol (Lemeshow, 1997). Jenis yang digunakan adalah pre test and post test nonequivalent control yaitu membentuk 2 kelompok dan masing-masing kelompok dilakukan pengukuran awal untuk menentukan skor awal sebelum perlakuan.

Kelompok perlakuan diberikan intervensi promosi kesehatan dengan pendekatan 7 dimensi budaya teori Sunrise Model yang dikemukakan oleh Leininger yaitu dimensi politik/kebijakan, agama, sosial, nilai budaya, ekonomi, tehnologi, dan edukasi. Promosi kesehatan melalui telepon genggam dilakukan oleh tokoh agama (kiai) kepada jamaah yang tergabung dalam grup whatssapp (aplikasi sosial media di handphone) berisi materi-materi pencegahan TB berbahasa Madura selama 2 minggu sebanyak 2 kali perhari sedangkan kelompok kontrol tidak diberikan intervensi (namun akan diberikan intervensi yang sama setelah penelitian selesai dilakukan).

Data populasi akan diseleksi sesuai dengan kriteria inklusi dan eksklusi melalui wawancara dengan pemegang program dan kiai terpilih. Kiai yang melaksanakan intervensi dipilih dengan menggunakan kriteria: 1. Suku Madura; 2. Islam; 3. memiliki jamaah/pesantren/ santri; 4. terbiasa menggunakan telepon genggam; 5. bersedia bekerjasama; Sampel penelitian ini menerapkan kriteria sampel yaitu kriteria inklusi dan ekslusi, yaitu: Kriteria inklusi: 1) Penduduk tetap (minimal 1 tahun) dibuktikan dengan KTP 2) Bersedia menjadi responden penelitian dan 3) Memiliki/ berkomunikasi memanfaatkan telepon genggam 4) Jamaah kiai terpilih. Sedangkan kriteria eksklusi adalah menderita gangguan yang menghambat komunikasi. Sampling yang digunakan adalah teknik simple random sampling dengan 50 responden di kelompok perlakuan dan 50 responden di kelompok kontrol.

Variabel bebas penelitian yaitu promosi kesehatan (dakwah) berbasis budaya sementara variabel terikatnya adalah efikasi diri pencegahan TB. Alat ukurnya menggunakan kuesioner yang dimodifikasi dari teori self efficacy Bandura.

Analisis statistik dengan uji paired t test digunakan untuk melihat perbedaan sebelum dan sesudah pemberian intervensi pada masingmasing kelompok. Sedangkan untuk mengetahui pengaruh dakwah antara kelompok perlakuan dan kelompok kontrol setelah intervensi dilakukan uji statistik independent $t$ test dengan tingkat signifikansi $\alpha \leq 0,05$.

\section{HASIL \& PEMBAHASAN}

\section{Hasil}

Tabel 1. Data karakteristik responden

\begin{tabular}{llcccc}
\hline \multirow{2}{*}{ Variabel } & \multicolumn{1}{c}{ Kategori } & \multicolumn{2}{c}{$\begin{array}{c}\text { Kelompok perlakuan } \\
(\mathbf{n = 5 0 )}\end{array}$} & \multicolumn{2}{c}{$\begin{array}{c}\text { Kelompok kontrol } \\
(\mathbf{n = 5 0})\end{array}$} \\
\cline { 3 - 6 } & & $\mathbf{n}$ & $\mathbf{\%}$ & $\mathbf{n}$ & $\mathbf{\%}$ \\
\hline Jenis kelamin & Laki-laki & 23 & 46 & 21 & 42 \\
& Perempuan & 27 & 54 & 29 & 58 \\
Usia & $<25$ & 4 & 8 & 4 & 8 \\
& $25-34$ & 4 & 8 & 3 & 6
\end{tabular}




\begin{tabular}{|c|c|c|c|c|c|}
\hline & $35-44$ & 23 & 46 & 28 & 56 \\
\hline & $45-54$ & 15 & 30 & 13 & 26 \\
\hline & $\geq 55$ & 4 & 8 & 2 & 4 \\
\hline \multirow{5}{*}{ Pendidikan } & Tidak sekolah & 4 & 8 & 3 & 6 \\
\hline & $\mathrm{SD} / \mathrm{MI}$ & 15 & 30 & 14 & 28 \\
\hline & SMP/MTs & 16 & 32 & 19 & 38 \\
\hline & SMA/MA & 13 & 26 & 11 & 22 \\
\hline & Kuliah & 2 & 4 & 3 & 6 \\
\hline \multirow[t]{5}{*}{ Pekerjaan } & Tidak bekerja & 6 & 12 & 6 & 12 \\
\hline & Wiraswasta & 16 & 32 & 17 & 34 \\
\hline & Tani & 16 & 32 & 14 & 28 \\
\hline & Dagang & 10 & 20 & 11 & 22 \\
\hline & Lain-lain & 2 & 4 & 2 & 4 \\
\hline \multirow[t]{3}{*}{ Status Perkawinan } & Belum & 3 & 6 & 4 & 8 \\
\hline & Kawin & 38 & 76 & 40 & 80 \\
\hline & Duda/janda & 9 & 18 & 6 & 12 \\
\hline \multirow[t]{3}{*}{ Jumlah Pendapatan } & $<750.000$ & 7 & 14 & 5 & 10 \\
\hline & $750.000-1.500 .000$ & 26 & 52 & 32 & 64 \\
\hline & $>1.500 .000$ & 17 & 34 & 13 & 26 \\
\hline \multirow{2}{*}{ Lama ikut pengajian } & $<5$ tahun & 9 & 18 & 7 & 14 \\
\hline & $\geq 5$ tahun & 41 & 82 & 43 & 86 \\
\hline
\end{tabular}

Tabel 2. Perbedaan efikasi diri pencegahan tuberkulosis pada kelompok perlakuan

\begin{tabular}{ccccc}
\hline Variabel & $\mathrm{n}$ & Median (min-maks) & Mean \pm SD & P value \\
\hline sebelum & 50 & $68(62-75)$ & $68,64 \pm 11,378$ & \multirow{2}{*}{0,000} \\
\hline sesudah & 50 & $76,50(68-85)$ & $76,88 \pm 3,497$ & \\
\hline
\end{tabular}

Tabel 3. Perbedaan efikasi diri pencegahan tuberkulosis pada kelompok kontrol

\begin{tabular}{ccccc}
\hline Variabel & $\mathrm{N}$ & Median (min-maks) & Mean \pm SD & P value \\
\hline sebelum & 50 & $68(60-75)$ & $68,04 \pm 3,289$ & \multirow{2}{*}{0,400} \\
\hline sesudah & 50 & $69(60-80)$ & $68,56 \pm 4,18$ & \\
\hline
\end{tabular}

Tabel 4. Analisis perbedaan perubahan efikasi diri yang mendapatkan dan tidak mendapatkan intervensi

\begin{tabular}{ccccc}
\hline Variabel & $\mathrm{N}$ & Median (min-maks) & Mean + SD & P value \\
\hline intervensi & 50 & $73(62-85)$ & $72,76 \pm 5,369$ & \multirow{2}{*}{0,000} \\
\hline kontrol & 50 & $68(60-80)$ & $68,3 \pm 3,751$ & \\
\hline
\end{tabular}

Sebagian besar responden berjenis kelamin perempuan pada kedua kelompok (54\% pada kelompok perlakuan dan $58 \%$ pada kelompok control), dan berusia antara 35-44 tahun. Mayoritas tingkat pendidikan responden pada kedua kelompok adalah Sekolah Menengah Pertama (SMP). Dengan pekerjaan sebagai wiraswasta dan pertanian. Sebagian besar responden pada kedua kelompok berstaus menikah.
Analisis perubahan efikasi diri sebelum dan sesudah intervensi pada kelompok perlakuan menggunakan uji paired t test mengahsilkan value $\mathrm{p}$ sebesar 0,000. Hasil ini menunjukkan adanya perbedaan yang signifikan efikasi diri antara sebelum dan sesudah intervensi promosi kesehatan (dakwah).

Analisis perubahan kondisi efikasi diri pada kelompok kontrol yang tidak 
mendapatkan intervensi menggunakan uji paired t test menghasilkan $\mathrm{p}$ value $=0,400$.

Analisis statistik perbedaan perubahan efikasi diri antara kelompok perlakuan dan kontrol setelah dilakukan promosi kesehatan (dakwah) berbasis budaya dengan uji independent $t$ test didapat hasil $p$ value $=0,000$ yang berarti ada pengaruh pemberian intervensi berbasis budaya dengan efikasi diri individu pada pencegahan tuberkulosis.

\section{Pembahasan}

Efikasi diri pada kedua kelompok sebelum diberikan dakwah via telepon genggam berbasis budaya relatif sama namun efikasi menjadi meningkat setelah diberikan dakwah pada kelompok perlakuan. Hasil uji statistik menunjukkan bahwa terdapat pengaruh promosi kesehatan (dakwah) via telepon genggam terhadap efikasi diri.

Responden penelitian sebagian besar berjenis kelamin perempuan dengan status menikah dan dengan pekerjaan sebagai wiraswasta dan tani. Perempuan di dalam rumah tangga memiliki peran dan tanggung jawab pada keluarganya. Hal ini berkaitan dengan faktor status dan peran individu dalam lingkungannya, dimana seseorang yang memiliki derajat kontrol yang tinggi cenderung memiliki efikasi yang lebih tinggi (Puspita, 2003). Penelitian Bandura (1997) menyatakan bahwa wanita efikasinya lebih tinggi dalam mengelola perannya. Wanita yang memiliki peran selain sebagai ibu rumah tangga, juga sebagai wanita karir akan memiliki keyakinan diri yang tinggi dibandingkan dengan laki-laki yang bekerja.

Pendidikan mempunyai peran yang penting dalam meningkatkan pengetahuan kepada masyarakat tentang pencegahan TB. Melalui pendidikan dan media massa dapat digunakan untuk mensosialisasikan pengetahuan tentang pencegahan TB sehingga dapat menyadarkan masyarakat bahwa penderita TB dapat hidup normal dan harus dilayani secara adil (Husniati, 2016).

Seseorang yang terbiasa bekerja dengan berbagai tingkat kesulitan akan dapat meningkatkan efikasi dirinya. Hal ini berkaitan dengan faktor sifat dari tugas yang dihadapi individu (Bandura, 1986). Namun, kondisi pekerjaan juga menjadi stressor karena kondisi kerja yang kurang kondusif, misal adanya persaingan antar rekan kerja, pekerjaan menumpuk, sehingga menurunkan keyakinan diri (Sukmayanti \& Ketut, 2014).

Pemberdayaan yang kurang dapat menurunkan keyakinan diri (self-efficacy) pada tingkat yang lebih umum dengan koping disfungsional dan tingkat yang lebih tinggi dari antisipasi terhadap stigma (Vauth, et al 2007).

Selama ini masih berlaku stigma TB sebagai penyakit karena keturunan dan gunaguna. Pendidikan agama yang diperoleh masyarakat jarang bahkan tidak membahas tentang pandangan agama terhadap penyakit. Sementara itu petugas kesehatan juga jarang menyentuh ke masyarakat. Hal ini menjadikan keyakinan diri masyarakat rendah terhadap pencegahan penyakit TB. Petugas kesehatan akan dapat meningkatkan hasil yang diinginkan yaitu penemuan kasus TB baru dengan lebih baik lagi jika mereka juga menggunakan dan memahami kondisi sosial budaya di masyarakat yang dapat membuat masyarakat menjadi berperilaku hidup sehat. Pendekatan budaya untuk kepentingan kesehatan harus dibuat dalam sebuah kebijakan dan pengimplementasian kebijakan tersebut (Napier et al., 2014)

Pendekatan budaya yang digunakan dalam penelitian ini adalah melalui promosi kesehatan yang dikemas menjadi dakwah oleh kiai. Predikat kiai berhubungan dengan suatu gelar kerohaniahan yang dikeramatkan, yang menekankan kemuliaan dan pengakuan, yang diberikan secara sukarela kepada ulama Islam pimpinan masyarakat setempat.

Pendekatan budaya ini selaras dengan penelitian yang menyatakan bahwa latar belakang pendidikan, ekonomi, nilai budaya dan gaya hidup, nilai sosial dan kekeluargaan, teknologi, spiritual dan berhubungan dengan kesehatan (Makhfudli, Rachmawati, \& Andini, 2017). Spiritualitas masyarakat Madura cukup kuat. Masyarakat Madura taat dan patuh secara hierarkis kepada empat figur utama dalam berkehidupan yaitu Buppa,' Babbu, Guru, ban Rato (Ayah, Ibu, Guru, dan Pemimpin 
pemerintahan). Guru yang dimaksud mengarah pada kiai/tokoh agama (Wiyata, 2003). Hal ini sesuai dengan konsep hovland \& weisz (1952) yang menyatakan bahwa seseorang yang kompeten dapat mempengaruhi keyakinan efikasi diri seseorang melalui pendekatan aktif. Persuasi verbal ini dilakukan oleh orang yang dianggap pakar atau memiliki kharisma pada orang lain (Oettingen, 1995).

Keadaan ini juga sejalan dengan teori bahwa keyakinan diri menurut Alwisol (2009) dapat diperoleh, diubah, ditingkatkan atau diturunkan, melalui salah satu atau kombinasi empat sumber, yakni pengalaman menguasai sesuatu prestasi (performance accomplishment), pengalaman vikarius (vicarious experiences), persuasi sosial (social persuation) dan pembangkitan emosi (emotional/physiological states).

Perspektif Max Weber (1966) dalam (Susanto, 2007) mengungkapkan bahwa kepemimpinan yang bersumber dari kekuasaan luar-biasa disebut charismatic authority. Kepemimpinan tersebut didasarkan pada identifikasi psikologis seseorang dengan orang lain. Terminologi identifikasi disini diartikan sebagai keterlibatan emosional seorang individu dengan individu lainnya. Bagi para pengikut, pemimpin adalah harapan untuk suatu kehidupan yang lebih baik dan dia dipandang sebagai pelindung dan sekaligus sebagai penyelamat (Poskas, Messer, Horntvedt, \& Vitcenda, 2013). Istilah kharisma menunjuk kepada kualitas kepribadian, sehingga dibedakan dengan orang kebanyakan.

Pemimpin dengan kharisma dianggap (bahkan diyakini) memiliki kekuatan supranatural sebagai manusia serba istimewa. Jika pengikut pemimpin ini telah terbiasa mengikuti pemimpin kharismanya, mereka menjadi tergantung kepada nasehat, bimbingan dan kemampuan pemimpinnya (Susanto, 2007). Peran dan kharisma kiai di komunitas Madura yang sangat dihormati baik di bidang keagamaan maupun bidang kesehatan. Dengan melakukan pendekatan pada masyarakat melalui figur yang dihormati oleh masyarakat setempat maka akan dapat membentuk efikasi diri seseorang dengan lebih mudah.

Materi dakwah yang berisi pencegahan TB dengan memperhatikan budaya seperti kolaborasi kiai sebagai penyampai pesan melalui telepon genggam, berbahasa madura, topik-topik mengangkat nilai budaya yang lekat pada masyarakat, dikaji dalam pandangan agama islam, aturan pemerintah menjadikan masyarakat mudah menerima persuasi yang dilakukan kiai.

Adanya sentuhan dakwah via telepon genggam berbasis budaya yang dilakukan oleh kiai menjadikan keyakinan diri meningkat. Bandura menjelaskan bahwa efikasi diri akan berkembang berangsur-angsur secara terus menerus seiring meningkatnya kemampuan dan bertambahnya pengalaman-pengalaman yang berkaitan dengan pengetahuan individu. Tingginya efikasi diri yang dipersepsikan akan memotivasi individu secara kognitif untuk bertindak secara tepat dan terarah. Efikasi diri yang positif menjadikan yakin bahwa mampu melakukan perilaku yang dimaksud. Tanpa efikasi diri (keyakinan tertentu yang sangat situsional), orang bahkan enggan melakukan suatu perilaku. Efikasi diri juga mempengaruhi besar usaha dan ketahanan individu dalam menghadapi kesulitan (Santrock, 2007).

Proses terbentuknya efikasi diri salah satunya dari kognitif atau pengetahuan. Dalam hal ini tindakan yang dilakukan seseorang yang berasal dari pikirannya. Kemudian pemikiran tersebut memberi arahan bagi tindakan yang dilakukan. Jika semakin tinggi pengetahuan, tingkat pendidikan, dan pekerjaan yang dimiliki akan memberikan konstribusi terhadap terbentuknya efikasi diri yang tinggi dan efikasi diri yang tinggi tidak dapat lepas dari adanya faktor-faktor yang mempengaruhi seperti pengalaman individu sebelumnya, pengalaman orang lain yang sama, persuasi sosial maupun keadaan fisiologis dan emosional (Masraroh, 2012).

Kuntjaraningrat berpendapat bahwa makin tinggi tingkat pendidikan seseorang, makin mudah menerima informasi sehingga makin banyak pula pengetahuan yang dimiliki (Pariani,2001). Jika pendapat dari Wied Hary A meskipun seseorang memiliki pendidikan yang rendah tetapi jika ia mendapatkan informasi yang baik maka hal itu akan dapat meningkatkan pengetahuan seseorang (Hendra AW, 2008). Menurut Bandura bahwa keyakinan diri dapat mempengaruhi setiap tingkat dari perubahan pribadi, baik saat 
individu tersebut mempertimbangkan perubahan kebiasaan yang berkaitan dengan kesehatan. Seseorang akan merasa yakin atas kemampuannya karena kehadiran pengalaman yang berkaitan dengan sebuah perilaku atau merasa yakin berdasarkan observasi yang dilakukan pada orang lain (Smet, 1997).

\section{SIMPULAN}

Efikasi diri meningkat dengan pemberian promosi kesehatan (dakwah) berbasis budaya

\section{SARAN}

Perawat kesehatan komunitas dapat mengembangkan strategi promosi kesehatan dengan mengintegrasikan budaya dan kearifan lokal dalam kegiatan, contohnya melibatkan peran tokoh panutan yang ada di masyarakat, melakukan kerjasama lintas sektoral seperti ormas agama (NU, muhammadiyah), tim penyuluh depag. Materi promosi kesehatan memuat hal-hal yang dekat dengan budaya setempat dan bersifat ajakan secara baik tanpa menyalahkan yang menyakiti perasaan masyarakat. Penggunaan telepon genggam dapat dikembangkan ke semua topik promosi kesehatan dengan memastikan keakuratan data (tidak ada unsur berita bohong) supaya informasi yang menjadi viral dapat bermanfaat bagi perkembangan ilmu kesehatan

\section{DAFTAR PUSTAKA}

Andrew, \& Boyle. (2003). Transcultural Concept in Nursing care (4th ed.). New York: Lippincott Williams \& Wilkins.

Arias, M. S., Eric Chamot, C., Managan, J. M., Cowan, C., Kristensen, S., \& Kimerling, M. E. (2010). Determinants of Self Efficacy to Seek Care for Tuberculosis and Complete Tuberculosis Treatment among HIV-Positive Individuals Attending HIV/AIDS Clinics in Honduras. The University of Alabama.

Arshad, A., Salam, R. A., \& Bhutta, Z. A. (2014). Community based interventions for the Prevention and Control of Tuberculosis. Infectious Diseases of Poverty, 3(27).

Baldwin, K. M., Baldwin, J. ., \& Ewald, T.
(2006). The relationship among shame, guilt, and self efficacy. American Journal of Psychotherapy, 60(1), 1-21.

Bandura, A. (1986). The Explanatory and Predictive Scope of Self EFficacy Theory. Journal OY Clinical and Social Psychology, 4, 359-373.

Dinkes Lumajang. (2014). Profil Dinas Kesehatan Lumajang. Lumajang.

Ditjen P2P. (2016). Temukan Obati Sampai Semb uh Tuberkulosis. Jakarta: Ditjen P2P.

Fauzan, L. A. (2014). Peran Ulama Melalui Komunikasi 2 Tahap dalam Program Keluarga Berencana.

Leininger, M., \& McFarland. (2006). Culture care diversity and universality: $A$ worldwide nursing theory. Boston: Jones \& Bartlett.

Napier, D., Ancarno, C., Butler, B., Calabrese, J., Chater, A., Chatterjee, H., ... Woolf, K. (2014). Culture and health. The Lancet, 384, 1607-39.

Neil, A. L., \& Christensen, H. (2009). Efficacy and Effectiveness of School-based Prevention and Early Intervension Program for Anxiety. Clinical Psycology, 208-215.

Oettingen, G. (1995). Cross-cultural Perspectives on Self Efficacy. In Bandura (Ed.), Self Efficacy in Changing Societies (pp. 149-176). New York: Cambridge University Press.

Poskas, D. A. T., Messer, C. C., Horntvedt, J., \& Vitcenda, M. E. (2013). Exploring the Impact of Charismatic Leaders in Communities.

Puspita, Y. (2003). Peran Ibu dalam Pembentukan Pola Konsumsi Pangan Keluarga Petani: Studi kasus. Universitas Diponegoro Semarang.

Rozaki, A. (2004). Menabur Kharisma Menuai Kuasa: Kiprah Kiai dan Blater sebagai Rezim Kembar di Madura (1st ed.). Yogyakarta: Pustaka Marwa.

Sukmayanti, \& Ketut. (2014). Efikasi Diri pada Pasien Diabetes Melitus Tipe 2. Politeknik Kesehatan Denpasar. Retrieved from http://poltekkesdenpasar.ac.id/files/JURNAL GEMA KEPERAWATAN/DESEMBER 2014/ARTIKEL I Gusti Ketut GedeNgurah 
$\mathrm{dkk}, . \mathrm{pdf}$

Susanto, E. (2007). [KHARISMATIK] PERSPEKTIF MADURA. Karsa, 11(1).

Turk, T., Newton, F. J., Newton, J. D., Naureen, F., \& Bokhari, J. (2013). Evaluating the Efficacy of Tuberculosis Advocacy, Communication and Social Mobilization (ACSM) Activities in Pakistan: A Cross
Sectional Study. BMC Public Health, 13(887).

WHO. (2009). Global Tuberculosis Control: Epidemiology, Strategy, Financing. (WHO, Ed.). Geneva.

WHO. (2013). Systematic screening for active tuberculosis: principles and recommendations. Genewa: World Health Organization. 